\section{IAC 2051: common bean cultivar of carioca type with slow seed coat darkening}

\author{
Sérgio Augusto Morais Carbonell ${ }^{1}$, Alisson Fernando Chiorato ${ }^{1}$, \\ Luiza Maria Capanema Bezerra ${ }^{1}$, João Guilherme Ribeiro \\ Gonçalves ${ }^{1}$, Sara Regina Silvestrin Rovaris ${ }^{1}$, Gabriel de Moraes \\ Cunha Gonçalves $^{1^{*}}$ and Jean Fausto de Carvalho Paulino ${ }^{2}$
}

\begin{abstract}
IAC 2051 is a common bean (Phaseolus vulgaris L.) cultivar with carioca-type seed coat, mean 1000 seed weight of $300 \mathrm{~g}$, indeterminate semiupright type II growth habit, slow post-harvest seed coat darkening, resistance to Fusarium wilt, common bacterial blight, and three races of anthracnose, and mean yield of $2729 \mathrm{~kg} \mathrm{ha}^{-1}$.
\end{abstract}

Keywords: Phaseolus vulgaris L., plant breeding, disease resistance.

\section{INTRODUCTION}

Common bean (Phaseolus vulgaris L.) is rich in protein, carbohydrates, vitamins, minerals, fibers, and antioxidant phenolic compounds (Silva et al. 2009). Brazilians consume an average of $17 \mathrm{~kg}^{\text {inhab }} \mathrm{b}^{-1} \mathrm{year}^{-1}$ of common bean, with frequency of three to seven times a week (Ribeiro et al. 2019). Among the different types of common bean grown, preference in the Brazilian consumer market is for carioca-type (cream-colored seed coat with brown streaks), followed by black bean, and then other types of bean grain (Faria et al. 2008).

In the 2018/2019 crop season, Brazil produced around 3.02 million metric tons of common bean in an area of 2.93 million hectares, led by the states of Paraná. In the same crop year, mean Brazilian yield was approximately $1031 \mathrm{~kg}$ $\mathrm{ha}^{-1}$, though the mean yield for the state of São Paulo was much higher: 2363 $\mathrm{kg} \mathrm{ha}^{-1}$ (CONAB 2020).

The increase in grain yield of common bean observed over the years is a result of improvement of crop management through use of inputs, suitable agronomic practices, and improved cultivars. Common bean breeding programs are important for increasing crop yield, and annual genetic gains obtained in common bean grain yield in Brazil range from 1.07\% to $6.74 \%$ (Chiorato et al. 2010, Barili et al. 2016).

Adoption of a common bean cultivar by farmers depends not only on grain yield but also on other characteristics, such as resistance/tolerance to biotic and abiotic factors that can interfere in bean development, nutritional quality, technological aspects, such as seed-coat darkening and cooking time, and post-harvest characteristics of the grain (Carbonell et al. 2010, Chiorato et al.
Crop Breeding and Applied Biotechnology 21(2): e36282128, 2021 Brazilian Society of Plant Breeding. Printed in Brazil http://dx.doi.org/10.1590/1984$70332021 v 21 n 2 c 37$
E-mail: gabriel_demoraes@hotmail.com (iD) ORCID: 0000-0001-9745-0929

Received: 27 December 2020 Accepted: 27 April 2021 Published: 20 June 2021

${ }^{1}$ Instituto Agronômico de Campinas, Centro de Análises e Pesquisa Tecnológica do Agronegócio dos Grãos e Fibras, 13.020-902, Campinas, SP, Brazil ${ }^{2}$ Instituto Agronômico de Campinas, Centro de Pesquisa e Desenvolvimento de Recursos Genéticos Vegetais, 13.020-902, Campinas, SP, Brazil 
2015). For the consumers, post-harvest quality merits consideration, especially slow seed darkening during storage since consumers associate dark bean grain color with difficulty in cooking (Silva et al. 2008).

Thus, the aim of this paper is to present the common bean cultivar IAC 2051 (Gen 2017-26-3-DA410) of carioca-type, which has high yield potential, slow post-harvest seed darkening, and resistance to Fusarium wilt (Fusarium oxysporum f. sp. phaseoli), common bacterial blight (Xanthomonas axonopodis pv. phaseoli), and three races of anthracnose (Colletotrichum lindemuthianum).

\section{GENETIC ORIGIN AND DEVELOPMENT}

The line Gen 2017-26-3-DA410 (IAC 2051) was developed from 2016 to 2018. In the winter of 2016, the carioca cultivar TAA Dama and the line SXB 410 (from the International Center for Tropical Agriculture [CIAT]), were crossed. From this cross, $20 \mathrm{~F}_{1}$ seeds were obtained. These seeds were sown in a greenhouse in the rainy season of 2016 to obtain seeds of the $F_{2}$ generation. This multiplication provided $350 \mathrm{~F}_{2}$ seeds.

In 2017, in the dry crop season, a sample of 50 pre-germinated $F_{2}$ seeds were transplanted to 5 -liter pots in a greenhouse to identify plants with light-colored grain and with slow seed coat darkening after storage for 90 days. From this evaluation, 30 plants that exhibited slow seed-coat darkening and high 100-seed weight, characteristics of line SXB 410, were separated. The 30 plants selected in $F_{2}$ were identified as Gen 2017-1-DA410 to Gen 2017-30-DA410, in which Gen is the abbreviation used by the Common Bean Plant Breeding Program of the IAC; 2017 is the year in which the progenies were obtained; the sequence from 1 to 30 represents the total of 30 progenies selected in the $F_{2: 3}$ generation; and the abbreviation DA410 refers to the parents used, with DA for the cultivar TAA Dama and 410 for the line SXB 410.

In the winter season of 2017, the 30 progenies were sown in a field on the Santa Elisa Farm of the Instituto Agronômico - IAC, Campinas, São Paulo. The seeds of each progeny were sown in 5-m rows at a spacing of $50 \mathrm{~cm}$ between rows. The aim of the experiment was to select plants within the progenies resistant to the soil pathogen Fusarium oxysporum $f$. sp. phaseoli. From this experiment was selected the progeny Gen 2017-26-DA410.

In the rainy season of 2017, each progeny of the $F_{2: 4}$ generation was sown in a 5-m row, spaced $0.5 \mathrm{~m}$ apart, in the municipality of Capão Bonito, São Paulo. Growth habit, grain yield, yield components, and grain quality after harvest were evaluated. Five plants were selected within Gen 2017-26-DA410, which were identified as Gen 2017-26-1-DA410 to Gen 2017-26-5-DA410, thus obtaining the $F_{2: 5}$ generation.

In 2018, in the dry season, the $F_{2: 5}$ progenies were sown in the municipality of Mococa, São Paulo. The randomized block experimental design, with three replications, was adopted. Growth habit, grain yield, resistance to soil pathogens, and post-harvest seed coat darkening were evaluated. To evaluate the seed coat darkening, a chamber with ultraviolet light was used for selection of lines with seed coats that did not darken at 24 hours of exposure to ultraviolet light (Spitti et al. 2019). The line Gen 2017-26-3-DA410 exhibited slow darkening of grain and was incorporated in the Value for Cultivation and Use (VCU) trials. These trials began in the winter season of 2018 and finished in the dry season of 2020 .

\section{YIELD POTENTIAL}

The mean grain yield of the line Gen 2017-26-3-DA410 (IAC 2051), compared to the three check cultivars, was higher in ten locations. In Mococa (dry season/2019), the cultivar IAC 2051 exhibited the highest yield (4250 kg ha-1) (Table 1).

In combined analysis (Table 2), line Gen 2017-26-3-DA410 (IAC 2051) had mean yield of $2729 \mathrm{~kg} \mathrm{ha}^{-1}$ in the VCU trials, which exceeded significantly the mean yield of the check cultivar IAC 1850 by $8 \%$. The cultivar IAC 2051 exceeded the mean yield of the cultivars IPR Sabiá and TAA Dama by 32 and $27 \%$, respectively.

Based on results obtained, the common bean breeding program of the Instituto Agronômico - IAC named the Gen 2017-26-3-DA410 line as IAC 2051. The name of the cultivar in reference to the number 20 corresponds to the year of release and the number 51 corresponds to the 51st common bean cultivar developed by the common bean breeding program of IAC. 


\section{OTHER CHARACTERISTICS}

The cultivar IAC 2051 has an indeterminate semi-upright type II growth habit, mean 1000 seed weight of 300 grams, mean cycle of 90 days from emergence to physiological maturity, mean grain cooking time of 30 min, and mean protein content of $20 \%$. In artificial inoculations with the pathogens that cause anthracnose (races 65, 83, and 89), Fusarium wilt (race 6), and common bacterial blight (XAP 19 isolate) (Table 3), under controlled conditions in the laboratory and greenhouse, the cultivar IAC 2051 exhibited resistance to these races and pathogens.

A between-row spacing of $50 \mathrm{~cm}$ and 12 plants per meter, which result in 240.000 plants per hectare, is recommended for the three cropping seasons. The yield of the cultivar IAC 2051 depends on the period of sowing, growing region, and technological level of the farmer (fertilization, disease and weed control, water supply, and other production factors).

Table 1. Grain yield of the cultivar IAC 2051 compared to the three check cultivars, in VCU experiments conducted in 18 environments in three crop seasons

\begin{tabular}{|c|c|c|c|c|c|c|c|}
\hline \multirow{2}{*}{ Municipality } & \multirow{2}{*}{ Crop season } & \multirow{2}{*}{$\begin{array}{l}\text { IAC } 2051 \\
\left(\mathrm{~kg} \mathrm{ha}^{-1}\right)\end{array}$} & \multicolumn{3}{|c|}{ Check $\left(\mathrm{kg} \mathrm{ha}^{-1}\right)^{*}$} & \multirow{2}{*}{$\begin{array}{l}\text { Mean yield of } \\
\text { checks }\end{array}$} & \multirow{2}{*}{ CV (\%) } \\
\hline & & & IAC 1850 & IPR Sabiá & TAA Dama & & \\
\hline Votuporanga & Winter/2018 & 3972 & 3527 & 2825 & 3327 & 3226 & 7 \\
\hline Campinas & Winter/2018 & 3858 & 3575 & 2192 & 2442 & 2736 & 12 \\
\hline Mococa & Winter/2018 & 1950 & 2183 & 1542 & 1658 & 1794 & 13 \\
\hline Mococa & Rainy/2018 & 2545 & 2167 & 2021 & 1967 & 2051 & 6 \\
\hline Capão Bonito & Rainy/2018 & 2312 & 2042 & 2313 & 1938 & 2097 & 8 \\
\hline Campinas & Dry/2019 & 2613 & 1438 & 1296 & 1363 & 1365 & 12 \\
\hline Mococa & Dry/2019 & 4250 & 4042 & 2642 & 2600 & 3094 & 14 \\
\hline Campinas & Winter/2019 & 2575 & 2308 & 2642 & 2171 & 2374 & 11 \\
\hline Mococa & Winter/219 & 2317 & 1950 & 1825 & 1700 & 1825 & 10 \\
\hline Votuporanga & Winter/2019 & 3008 & 2875 & 1967 & 2100 & 2314 & 9 \\
\hline Campinas & Dry/2020 & 2842 & 2117 & 1933 & 1267 & 1772 & 18 \\
\hline Tatuí & Dry/2020 & 1921 & 1675 & 1302 & 1683 & 1553 & 8 \\
\hline Mococa & Dry/2020 & 268 & 442 & 260 & 200 & 301 & 13 \\
\hline
\end{tabular}

*IAC 1850: indeterminate type II growth habit, semierect plant architecture, and resistence to the main diseases in common bean (Carbonell et al. 2019); IPR Sabiá: indeterminate type II growth habit and erect plant architecture; TAA Dama: indeterminate type III growth habit, prostrate plant architecture, and tolerance to seed coat darkening.

Table 2. Grain yield of the cultivar IAC 2051 in relation to the best check cultivar for growing in the three common bean crop seasons, as well as in relation to the combined mean of the trait in 18 environments of the state of São Paulo in 2018, 2019, and 2020

\begin{tabular}{lcccc}
\hline & & $\begin{array}{c}\text { Crop season } \\
\left(\mathrm{kg} \mathrm{ha}^{-1}\right)\end{array}$ & \multicolumn{2}{c}{$\begin{array}{c}\text { Combined mean } \\
\left(\mathrm{kg} \mathrm{ha}^{-1}\right)\end{array}$} \\
\cline { 2 - 4 } Common bean cultivar & $\begin{array}{c}\text { Rainy } \\
\text { (6 environments) }\end{array}$ & $\begin{array}{c}\text { Dry } \\
\text { (6 environments) }\end{array}$ & $\begin{array}{c}\text { Winter } \\
\text { (6 environments) }\end{array}$ \\
\hline IAC 2051 & 2946 & $2294^{*}$ & $2946^{*}$ & $2729^{*}$ \\
IAC 1850 & 2903 & 1911 & 2736 & 2516 \\
IPR Sabiá & 2440 & 1585 & 2165 & 2063 \\
TAA Dama & 2659 & 1618 & 2232 & 2137 \\
\hline Mean & 2373 & 1794 & 2303 & 10 \\
CV (\%) & 11 & 15 & 2157 \\
LSD (kg ha $\left.{ }^{-1}\right)^{*}$ & 244 & 260 & 231 & 12 \\
\hline
\end{tabular}

*significant at $5 \%$ by the Dunnett test. 
Table 3. Reaction of four cultivars of common bean to anthracnose (ANT), Fusarium wilt (FW), and common bacterial blight (CBB) artificially inoculated under laboratory conditions and greenhouse

\begin{tabular}{lccc}
\hline Common bean cultivars & $\begin{array}{c}\mathrm{ANT}^{\mathrm{a}} \\
\text { (Races 65, 83, and 89) }\end{array}$ & $\begin{array}{c}\text { FW }^{\mathrm{b}} \\
\text { (Race 6) }\end{array}$ & $\begin{array}{c}\mathrm{CBB}^{\mathbf{c}} \\
\text { (Isolate XAP 19) }\end{array}$ \\
\hline IAC 2051 & $\mathrm{R}$ & $\mathrm{R}$ & $\mathrm{R}$ \\
IAC 1850 & $\mathrm{R}$ & $\mathrm{R}$ & $\mathrm{MR}$ \\
IPR Sabiá & $\mathrm{R}$ & $\mathrm{R}$ & $\mathrm{R}$ \\
TAA Dama & $\mathrm{S}$ & $\mathrm{MR}$ & $\mathrm{R}$ \\
\hline
\end{tabular}

R: resistant to the pathogen; MR: moderately resistant to the pathogen; S: susceptible to the pathogen

${ }^{a}$ scoring scale adapted from Pastor-Corrales et al. (1995) using notes from 1 to 9 . The plants with scores 1.0 to 3.0 were classified as resistant; from 3.1 to 6.0 as moderately resistant and from 6.1 to 9.0 as susceptible.

${ }^{b}$ scoring scale adapted from Pastor-Corrales and Abawi (1987) using notes from 1 to 9 . The plants with scores 1.0 to 3.0 were classified as resistant; from 3.1 to 6.0 as moderately resistant and from 6.1 to 9.0 as susceptible.

${ }^{c}$ scoring scale adapted from Rava (1984) using notes from 1 to 6 . The plants with scores 1.0 to 2.0 were classified as resistant; from 2.1 to 4.0 as moderately resistant and from 4.1 to 6.0 as susceptible.

\section{TECHNICAL RECOMMENDATIONS AND SEED PRODUCTION}

Considering its high mean yield and 1000-seed weight in addition to its slow seed-coat darkening, the cultivar IAC 2051 is recommended for growing in the rainy, dry, and winter crop seasons in the state of São Paulo, and for the rainy and dry crop seasons in the states of Paraná, Santa Catarina, Rio Grande do Sul, and Mato Grosso do Sul.

The IAC 2051 cultivar was registered in the National Cultivar Registry (Registro Nacional de Cultivares - RNC) of the Brazilian Ministry of Agriculture (Ministério da Agricultura, Pecuária e Abastecimento - MAPA) on August 3, 2020, under number 44819 and has seed production available in the Núcleo de Produção de Sementes do Instituto Agronômico - IAC.

\section{REFERENCES}

Barili LD, Vale NM, Moura LM, Paula RG, Silva FF and Carneiro JES (2016) Genetic progress resulting from forty-three years of breeding of the carioca common bean in Brazil. Genetics and Molecular Research 15: gmr.15038523.

Carbonell SAM, Chiorato AF, Bezerra LMC, Gonçalves JGR, Silva DA, Esteves JAF, Benchimol-Reis LL, Carvalho CRL, Barros VLNP, Freitas RS, Ticelli $M$ and Gallo PB (2019) IAC 1850: High yielding carioca common bean cultivar. Crop Breeding and Applied Biotechnology 19: 378-381.

Carbonell SAM, Chiorato AF, Gonçalves JGR, Perina EF and Carvalho CRL (2010) Tamanho de grão comercial em cultivares de feijoeiro. Ciência Rural 40: 2067-2073.

Chiorato AF, Carbonell SAM, Bosetti F, Sasseron GR, Lopes RLT and Azevedo CVG (2015) Common bean genotypes for agronomic and marketrelated traits in VCU trials. Scientia Agricola 72: 34-40.

Chiorato AF, Carbonell SAM, Vencovsky R, Fonseca Júnior NS and Pinheiro $J B(2010)$ Genetic gain in the breeding program of common beans at IAC from 1989 to 2007. Crop Breeding and Applied Biotechnology 10: 329-336.

CONAB - Companhia Nacional de Abastecimento (2020) Acompanhamento da safra brasileira de grãos. Available at <https://www.conab.gov. $\mathrm{br} /$ info-agro/safras/graos/boletim-da-safra-de-graos?start=10>. Accessed on July 31, 2020.

Faria LC, Peloso MJD, Melo LC, Costa JGC, Rava CA, Díaz JLC, Faria JC, Silva HT, Sartorato A, Bassinello PZ and Trovo JBF (2008) BRS Cometa: a carioca common bean cultivar with erect growth habit. Crop Breeding and Applied Biotechnology 8: 167-169.

Pastor-Corrales MA and Abawi GS (1987) Reactions of selected bean germplasms to infection by Fusarium oxysporum f. sp. phaseoli. Plant Disease 71: 990-993.

Pastor-Corrales MA, Otoya MM, Molina A and Singh SP (1995) Resistance to Colletotrichum lindemuthianum isolates from middle America and Andean South America in different common bean races. Plant Disease 79: 63-67.

Rava CA (1984) Patogenicidade de isolados de Xanthomonas campestres pv. phaseoli. Pesquisa Agropecuária Brasileira 19: 445-448.

Ribeiro ND, Casagrande CR, Mezzomo HC, Kläsener GR and Steckling SM (2019) Consumer preference and the technological, cooking and nutritional quality of carioca beans. Semina: Ciências Agrárias 40: 651-664.

Silva AG, Rocha LC and Canniatti BSG (2009) Caracterização físico-química, digestibilidade protéica e atividade antioxidante de feijão comum (Phaseolus vulgaris L.). Alimentos e Nutrição 20: 591-598.

Silva GS, Ramalho MAP, Abreu AFB and Silva FB (2008) Genetic control of early grain darkening of carioca common bean. Crop Breeding and Applied Biotechnology 8: 299-304.

Spitti AMDS, Carbonell SAM, Dias CTS, Sabino LG, Carvalho CRL and Chiorato AF (2019) Carioca bean genotypes for tolerance to grain darkening by natural and accelerated methods. Ciência e Agrotecnologia 43: 1-10. 